\title{
EFFECTS OF SOME ECOLOGICAL FACTORS ON DISTRIBUTION OF PRANGOS ULOPTERA AND PRANGOS PABULARIA IN RANGELANDS OF ARDABIL PROVINCE, IRAN
}

\author{
Mossivand, A. M. - GHORBANI, A. ${ }^{*}-$ BeHJOU, F. K. \\ Department of Range \& Watershed Management, University of Mohaghegh Ardabili \\ Ardabil, Iran \\ *Corresponding author \\ e-mail:a_ghorbani@uma.ac.ir \\ (Received $13^{\text {th }}$ Dec 2016; accepted 24 $4^{\text {th }}$ Mar 2017)
}

\begin{abstract}
The aim of this study is to assess the effects of some environmental factors on the distribution of Prangos uloptera DC. and Prangos pabularia Lindl. In the rangelands of Ardabil province, in the north-west of Iran. Six sites with the distribution of the genus Prangos (presence) and six sites without Prangos (absence) were identified. Three $100 \mathrm{~m}$ transects were established. On each transect, ten $4 \mathrm{~m}^{2}$ plots were located, and the total canopy cover and density of plants were recorded. Soil samples were collected from a depth of $0-30 \mathrm{~cm}$ on each transect. Elevation, slope and aspect were extracted from the Digital Elevation Model (DEM), and rainfall, temperature were also extracted from the derived gradient equation and DEM for each plot. Soil parameters such as organic matter $(\mathrm{OM})$, nitrogen $(\mathrm{N})$, phosphate $(\mathrm{P})$, potassium $(\mathrm{K}), \mathrm{pH}$, electric conductivity (EC) and texture were determined at the Soil Lab. Normality of data was tested. To compare the related parameters for the sites with the presence and absence of species, the one-way ANOVA was conducted. Cluster analysis was used to classify the collected samples. To determine the variables that were significant in the distinction of each groups and mean comparison, ANOVA and Tukey tests were conducted. To determine the importance of ecological factors for the presence and absence of the selected species, discriminant analysis was conducted. The results of the analysis of variance between presence and absence of $P$. uloptera and $P$. pabularia in habitats demonstrated significant differences for the parameters of elevation, slope, aspect, temperature, EC, $\mathrm{pH}$, $\mathrm{OM}$, nitrogen, phosphorus, clay, silt and sand and total canopy cover, $\mathrm{P}<0.01$. The result of grouping sampling plots using cluster analysis showed that plots in three groups were separated by significant differences $(\mathrm{P}<0.05)$ in the multivariate analysis of variance. The results showed that $P$. uloptera was adapted in habitats with OM of $1.402 \%$, N $0.126 \%$, P $2.627_{\mathrm{ppm}}, \mathrm{K} 258_{\mathrm{ppm}}, 1992 \mathrm{~m}$ a.s.l., with average slope of $83.40 \%$, clay $10.90 \%$, silt $37.90 \%$, sand $51.20 \%$, and average precipitation of $353 \mathrm{~mm}$. However, P. pabularia was adapted in habitats with OM of $0.915 \%, \mathrm{~N} 0.088 \%, \mathrm{P} 2.339_{\mathrm{ppm}}, \mathrm{K} 236_{\mathrm{ppm}}, 1672 \mathrm{~m}$ a.s.l., and with average slope of $84.80 \%$, clay $13.60 \%$, silt $29.70 \%$, sand $56.70 \%$ and average precipitation of $370 \mathrm{~mm}$. With regard to the results from discriminant analysis, the percentages of slope, clay, sand, silt, $\mathrm{OM}, \mathrm{P}$ and $\mathrm{pH}$, aspect, precipitation and temperature play an effective role in the separation and distribution of the species studied. These results can be used to suggest suitable species in management and restoration of rangelands with the same ecological characteristics.
\end{abstract}

Keywords: ecological factors, species dispersion, cluster analysis, discriminant analysis

\section{Introduction}

Environmental factors affect the establishment and distribution of plant species (Ashcroft et al., 2011). Identification of factors that affect the distributions of species is an important unresolved issue in ecology (Araújo and Guisan, 2006). Often, there are many combinations of predictors that can explain distributions equally well, especially when environmental factors are correlated, and this introduces uncertainty into the effect of each factor (Platts et al., 2008; Murray and Conner, 2009). Therefore, the first step in rangeland management is to determine the habitats of plants and the effective factors affecting their distribution. Autecological field or laboratory studies have long 
been relied upon to reveal environmental variables that impede a plant's migration into surrounding territory (Arundel, 2005). These variables-or limiters-shape various spatial aspects of individual plant species' distributions. Knowing specific influences on plants is important in many fields, but particularly for climate reconstruction based on fossil plant remains (Arundel, 2002). The presence and distribution of plant species in rangeland ecosystems are not random, but such factors as climate, soil, topography, anthropological and others play major roles in their development (Akbarlou and Nodehi, 2016). Determination of the factors that control the presence and distribution of rangeland species is one of the main objectives in the rangeland ecosystems studies.

Though relationships between plant and both soil properties and other environmental factors have been well developed for some plants, comparable understanding of how a variety of plant species in native rangelands responds to soil properties and other environmental factors is poorly developed (Chuangye et al., 2015; Ghorbani et al., 2015; Sahragard and Zare Chahouki, 2015). Xu et al. (2008a) have studied the relationships between vegetation, soil and topography in the dry valley of China. Their results confirmed that plant diversity was mainly correlated with soil water content, and soil water content was mainly determined by soil texture, especially clay content. Yibing (2008), by conducting the Principal Component Analysis (PCA) and Canonical Correlation Analysis in China, showed that physical and chemical features of the soil, including humidity, salinity and acidity affected homogeneity of plant communities on the regional scale. Zhang and Dong (2010), in the study of relationships between environmental factors and vegetation diversity in Lesi plateau of China, reported that elevation, soil type, slope and aspect were important factors in Lesi zones' recovery, and had determinant roles in vegetation distribution. Zare et al. (2011), in a study on the relationship between environmental factors and plant distribution in arid and semiarid areas, reported that soil texture, salinity, effective soil depth, available N, K, OM, lime and soil moisture, were the major soil factors responsible for variations in the pattern of vegetation. Ghorbani and Asghari (2014), in the study of ecological factors affecting the distribution of Festuca ovina in the southeastern rangelands of Sabalan, reported that $F$. ovina is more compatible with higher altitudes and lower temperatures and does not tolerate soil salinity, and is more compatible with a $\mathrm{pH}$ of 7.1 to 7.3. OM, $\mathrm{P}$ and $\mathrm{K}$ provide better conditions for its growth.

To improve the management of rangelands and to offer a baseline for restoration attempts, an understanding of the factors that determine the rangelands vegetation distribution and composition is required. For this purpose, this study was conducted to identify the roles of topography, climate and soil components, in the distribution of Prangos uloptera and P. pabularia, in the rangelands of Ardabil province in northwestern Iran. Identification of these parameters in a given ecosystem helps one apply appropriate management for restoration and development in the present and in similar rangelands.

\section{Materials and Methods}

\section{Study area}

The study area was selected in the rangelands of Ardabil province, Iran $\left(37^{\circ} 12^{\prime}\right.$ to $38^{\circ} 07^{\prime} \mathrm{N}$ and $47^{\circ} 51^{\prime}$ to $48^{\circ} 48^{\prime} \mathrm{E}$ ) (Figure 1). Six habitats were selected with the genus Prangos distribution. P. uloptera were distributed in four habitats and P. pabularia were in two habitats. According to meteorological stations in the region (with a 10-year 
period-2006 to 2015), the mean precipitation is $360 \mathrm{~mm} /$ year. Also, maximum and minimum precipitations respectively occur in February and July. The mean of annual temperature is $9^{\circ} \mathrm{C}$, the average annual minimum temperature is $3.2^{\circ} \mathrm{C}$ and the average annual maximum temperature is $14.8^{\circ} \mathrm{C}$.

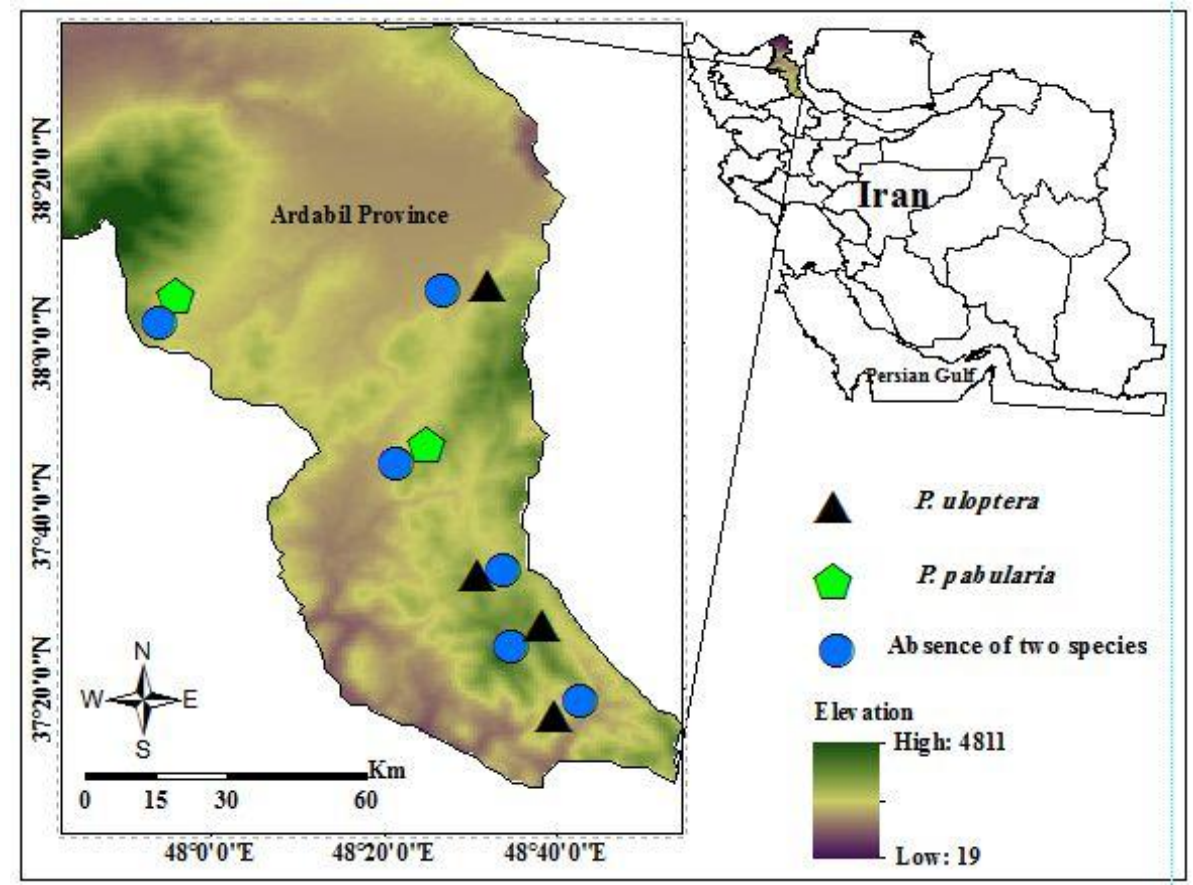

Figure 1. Location of the study area and sampling locations for presence and absence of the selected species in Ardabil province and Iran

\section{Sampling method}

Initially, in order to recognize the distribution of the genus Prangos, an overall study was conducted by literature review (Rechinger, 1987; Mozaffarian, 2007; Azimi et al., 2011; Teimoorzadeh et al., 2015; Ghorbani et al., 2015). Moreover, fieldworks were conducted in Ardabil province to select the habitat of the genus Prangos. Finally, six habitats were identified with P. uloptera and P. pabularia distributions. In each habitat, initially one site with genus Prangos distribution was selected as the presence of the selected species. Near to each of the selected sites, another site with the absence of genus Prangos were selected in the same habitat (overall, for the presence and absences of genus Prangos, 12 sites were selected). A Digital Elevation Model (DEM) map was derived using 1:25000 topographic maps of the National Cartographic Center of Iran, with $10 \mathrm{~m}$ horizontal and vertical accuracy. Slope and aspect maps were derived from the DEM for the selected habitats and sites. By considering the studies conducted on the rangelands of Ardabil province (i.e. Ghorbani and Asghari, 2014; Ghorbani et al., 2015), in each site three $100 \mathrm{~m}$ transects were established. The first one was selected randomly, and the second one as parallel with $500 \mathrm{~m}$ distance, and the third one perpendicular to both. By considering the abovementioned literature and using minimal area method (Kent and Coker, 1996), the size of plots was determined as $4 \mathrm{~m}^{2}$. The number of plots was also determined by considering the literature (i.e. Ghorbani and Asghari, 2014; Ghorbani et al., 2015), and the pre-samples taken were calculated 
(Kerbs, 1999) as about 10 samples. Overall, ten $4 \mathrm{~m}^{2}$ plots were selected for each transect, wherein the distance between the plots (from the centre of each one) was $10 \mathrm{~m}$, for the 12 selected sites, for the presence and absence of species. Within each plot (presence and absence of the species), total canopy cover, percentage and density of plants, including the selected species, were recorded. In each site, nine soil samples were collected from the depth of $(0-30 \mathrm{~cm})$ (Northup et al., 1996). The soil propertiessuch as N, OM, EC, pH, P, K and texture-were measured via laboratory analysis at the Soil Lab of Ardabil University.

\section{Data analysis}

Kolmogorov-Smirnov test was used to assess the normality of data. To analyse significant difference between the effects of environmental factors on the presence or absence of two selected species, the one-way ANOVA was used. For grouping the collected samples on the basis of the recorded ecological factors, cluster analysis was used. To determine the variables that assume significance in the distinction of identified groups and to compare these, ANOVA and Tukey test were used. The importance of each measured variable in the distribution of selected species was analysed using discriminant analysis. The ArcGIS10 was used to extract the base map and SPSS18 software was used for data analysis.

\section{Results}

The results of the analysis of variance between presence and absence of $P$. uloptera and $P$. pabularia in habitats demonstrated significant difference for the parameters of elevation, slope, aspect, temperature, EC, $\mathrm{pH}, \mathrm{OM}$, nitrogen, phosphorus, clay, silt and sand and total canopy cover, $\mathrm{P}<0.01$ (Table 1). The clustering of sampling plots, using cluster analysis, indicated that the plots are divided into three groups $(\mathrm{P}<0.01)$ in the multivariate analysis of variance (Figure 2). The discrimination based on the plots revealed that Group 1 is related to the absence of the two species in the habitats, Group 2 shows the habitat of $P$. uloptera, and Group 3 indicates the habitat of P. pabularia. The results of multivariate analysis of variance among the groups proved that the resultant groups had significant differences in all the variables, except for the precipitation level and potassium, $\mathrm{P}<0.01$ (Table 2). The elevation, organic matter and silt in the habitat of $P$. uloptera (Group 2) were higher than the habitat of $P$. pabularia and the habitats without the study species, which had significant difference, $\mathrm{P}<0.01$ (Table 2). In the habitat of $P$. pabularia (Group 3), the percentage of sand and temperature were higher than other habitats, which had significant difference $(\mathrm{P}<0.01)$, as well as the habitats without the study species had the highest electrical conductivity, clay and phosphorus compared to other habitats $(\mathrm{P}<0.01)$. The slope in the habitats of $P$. uloptera and $P$. pabularia had the highest percentage (over 83\%) and the habitats without the study species had lower percentage (mean slope of 66\%). The results showed that P. uloptera was adapted in habitats with average $\mathrm{OM}$ of $1.402 \%, \mathrm{~N}$ $0.126 \%$, P 2.627 ppm, K 258 $\mathrm{ppm}, 1992 \mathrm{~m}$ elevation a.s.l., slope $83.40 \%$, clay $10.90 \%$, silt $37.90 \%$, sand $51.20 \%$, and also average precipitation of $353 \mathrm{~mm}$. However, P. pabularia was adapted in habitats with average OM $0.915 \%, \mathrm{~N} 0.088 \%, \mathrm{P} 2.339_{\mathrm{ppm}}, \mathrm{K} 236_{\mathrm{ppm}}$, $1672 \mathrm{~m}$ elevation a.s.1., average slope $84.80 \%$, clay $13.60 \%$, silt $29.70 \%$, sand $56.70 \%$, and also average precipitation of $370 \mathrm{~mm}$. 
Table 1. Analysis of variance of environmental factors and their effects on the presence or absence of $P$. uloptera and P. pabularia

\begin{tabular}{|c|c|c|c|c|}
\hline & & Sum of Squares & df & $\mathbf{F}$ \\
\hline Elevation (m) & $\begin{array}{l}\text { Between Groups } \\
\text { Within Groups }\end{array}$ & $\begin{array}{c}36923549.214 \\
39461.356\end{array}$ & $\begin{array}{c}2 \\
33\end{array}$ & $19.033^{* *}$ \\
\hline Slope \% & $\begin{array}{l}\text { Between Groups } \\
\text { Within Groups }\end{array}$ & $\begin{array}{c}64745.081 \\
2881.912\end{array}$ & $\begin{array}{c}2 \\
33\end{array}$ & $125.221^{* *}$ \\
\hline Aspect & $\begin{array}{l}\text { Between Groups } \\
\text { Within Groups }\end{array}$ & $\begin{array}{c}500.211 \\
27.389\end{array}$ & $\begin{array}{c}2 \\
33\end{array}$ & $9.949^{* *}$ \\
\hline Precipitation (mm) & $\begin{array}{l}\text { Between Groups } \\
\text { Within Groups }\end{array}$ & $\begin{array}{c}1370579.678 \\
4879.101\end{array}$ & $\begin{array}{c}2 \\
33\end{array}$ & $1.384^{\mathrm{ns}}$ \\
\hline Temperature $\left(\mathrm{C}^{\mathrm{O}}\right)$ & $\begin{array}{l}\text { Between Groups } \\
\text { Within Groups }\end{array}$ & $\begin{array}{c}403.843 \\
27.899\end{array}$ & $\begin{array}{c}2 \\
33\end{array}$ & $12.331^{* *}$ \\
\hline $\mathrm{EC}(\mathrm{Ds} / \mathrm{m})$ & $\begin{array}{l}\text { Between Groups } \\
\text { Within Groups }\end{array}$ & $\begin{array}{l}1.336 \\
0.242\end{array}$ & $\begin{array}{c}2 \\
33\end{array}$ & $31.840^{* *}$ \\
\hline $\mathrm{pH}$ & $\begin{array}{l}\text { Between Groups } \\
\text { Within Groups }\end{array}$ & $\begin{array}{l}8.403 \\
1.603\end{array}$ & $\begin{array}{c}2 \\
33\end{array}$ & $34.046^{* *}$ \\
\hline OM\% & $\begin{array}{l}\text { Between Groups } \\
\text { Within Groups }\end{array}$ & $\begin{array}{c}99.024 \\
9.800\end{array}$ & $\begin{array}{c}2 \\
33\end{array}$ & $17.665^{* *}$ \\
\hline $\mathrm{N} \%$ & $\begin{array}{l}\text { Between Groups } \\
\text { Within Groups }\end{array}$ & $\begin{array}{l}0.864 \\
0.057\end{array}$ & $\begin{array}{c}2 \\
33\end{array}$ & $11.705^{* *}$ \\
\hline $\mathrm{P}(\mathrm{ppm})$ & $\begin{array}{l}\text { Between Groups } \\
\text { Within Groups }\end{array}$ & $\begin{array}{c}370.154 \\
13.940\end{array}$ & $\begin{array}{c}2 \\
33\end{array}$ & $6.722^{* *}$ \\
\hline $\mathrm{K}(\mathrm{ppm})$ & $\begin{array}{l}\text { Between Groups } \\
\text { Within Groups }\end{array}$ & $\begin{array}{c}1770318.244 \\
19596.654\end{array}$ & $\begin{array}{c}2 \\
33\end{array}$ & $1.976^{\mathrm{ns}}$ \\
\hline Clay\% & $\begin{array}{l}\text { Between Groups } \\
\text { Within Groups }\end{array}$ & $\begin{array}{c}10490.046 \\
421.744\end{array}$ & $\begin{array}{c}2 \\
33\end{array}$ & $83.939^{* *}$ \\
\hline Silt $\%$ & $\begin{array}{l}\text { Between Groups } \\
\text { Within Groups }\end{array}$ & $\begin{array}{c}29395.534 \\
279.344\end{array}$ & $\begin{array}{c}2 \\
33\end{array}$ & $17.834^{* *}$ \\
\hline Sand $\%$ & $\begin{array}{l}\text { Between Groups } \\
\text { Within Groups }\end{array}$ & $\begin{array}{c}21747.143 \\
1668.023\end{array}$ & $\begin{array}{c}2 \\
33\end{array}$ & $34.008^{* *}$ \\
\hline Density $P$. uloptera & $\begin{array}{l}\text { Between Groups } \\
\text { Within Groups }\end{array}$ & $\begin{array}{c}35.600 \\
3.220\end{array}$ & $\begin{array}{c}2 \\
33\end{array}$ & $197.225^{* *}$ \\
\hline Density P. pabularia & $\begin{array}{l}\text { Between Groups } \\
\text { Within Groups }\end{array}$ & $\begin{array}{l}2.722 \\
0.752\end{array}$ & $\begin{array}{c}2 \\
33\end{array}$ & $277.272^{* *}$ \\
\hline Total Canopy Cover & $\begin{array}{l}\text { Between Groups } \\
\text { Within Groups }\end{array}$ & $\begin{array}{c}6430.225 \\
245.368\end{array}$ & $\begin{array}{c}2 \\
33\end{array}$ & $101.987^{* *}$ \\
\hline
\end{tabular}

\footnotetext{
*** ns: Respectively significant at $1 \%$ and non-significant
} 


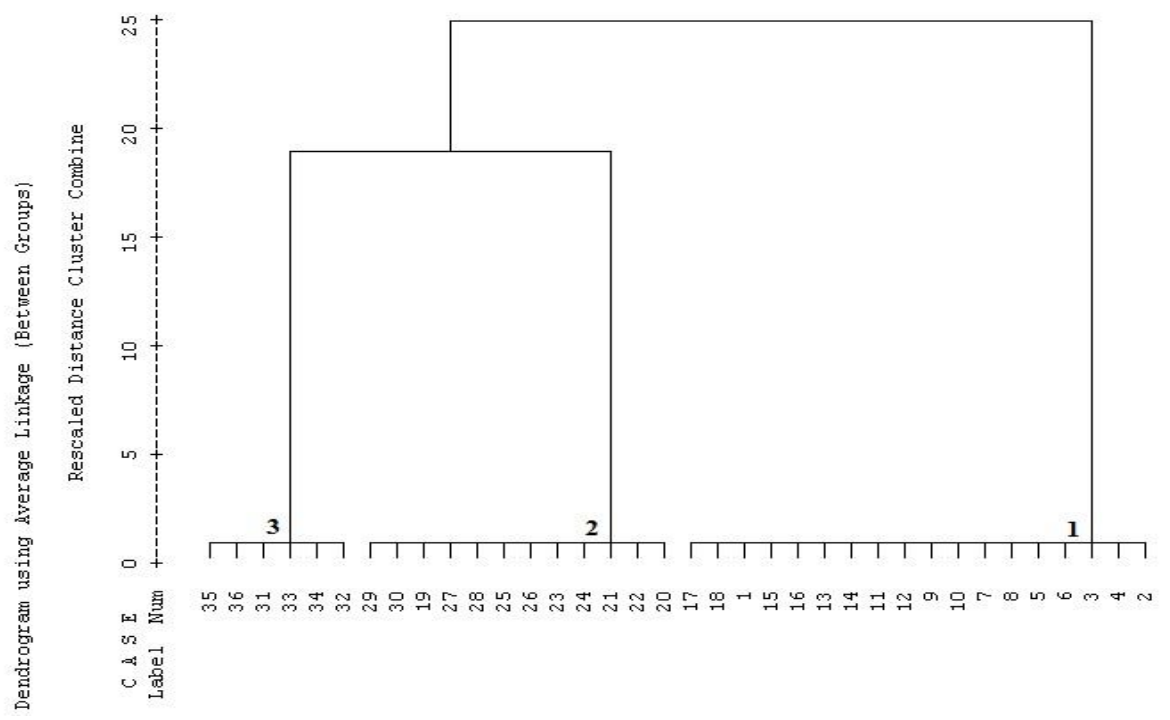

Figure 2. Cluster analysis of ecological factors and density of P. uloptera and P. pabularia using cluster analysis method

Table 2. Comparison of measured characteristics in the conditions of the presence and absence of species

\begin{tabular}{l|c|c|c|c|c|c}
\hline & \multicolumn{2}{|c|}{$\begin{array}{c}\text { Absence of two } \\
\text { species (1) }\end{array}$} & \multicolumn{2}{c|}{ P. uloptera (2) } & \multicolumn{2}{c}{ P. pabularia (3) } \\
\hline & Mean & Std. Error & Mean & Std. Error & Mean & Std. Error \\
Elevation (m) & $1861^{\mathrm{b}}$ & 28.000 & $1992^{\mathrm{a}}$ & 26.000 & $1672^{\mathrm{c}}$ & 22.000 \\
Slope\% & $66.300^{\mathrm{b}}$ & 0.919 & $83.400^{\mathrm{a}}$ & 0.765 & $84.800^{\mathrm{a}}$ & 1.084 \\
Aspect & $0.012^{\mathrm{b}}$ & 0.001 & $0.013^{\mathrm{b}}$ & 0.001 & $0.012^{\mathrm{b}}$ & 0.001 \\
Precipitation & $359^{\mathrm{a}}$ & 4.620 & $353^{\mathrm{a}}$ & 6.843 & $370^{\mathrm{a}}$ & 1.539 \\
(mm) & & & & & & \\
Temperature $\left(\mathrm{C}^{\mathrm{o}}\right)$ & $8.943^{\mathrm{b}}$ & 0.081 & $8.665^{\mathrm{b}}$ & 0.061 & $9.499^{\mathrm{a}}$ & 0.196 \\
EC (Ds/m) & $0.537^{\mathrm{a}}$ & 0.005 & $0.487^{\mathrm{b}}$ & 0.004 & $0.480^{\mathrm{b}}$ & 0.008 \\
pH & $7.679^{\mathrm{a}}$ & 0.011 & $7.535^{\mathrm{b}}$ & 0.014 & $7.666^{\mathrm{a}}$ & 0.021 \\
OM\% & $1.181^{\mathrm{b}}$ & 0.037 & $1.402^{\mathrm{a}}$ & 0.055 & $0.915^{\mathrm{c}}$ & 0.058 \\
N\% & $0.113^{\mathrm{a}}$ & 0.004 & $0.126^{\mathrm{a}}$ & 0.005 & $0.088^{\mathrm{b}}$ & 0.006 \\
P (ppm) & $2.875^{\mathrm{a}}$ & 0.086 & $2.628^{\mathrm{ab}}$ & 0.092 & $2.339^{\mathrm{b}}$ & 0.051 \\
K (ppm) & $250^{\mathrm{a}}$ & 3.188 & $258^{\mathrm{a}}$ & 9.810 & $236^{\mathrm{a}}$ & 4.403 \\
Clay\% & $17.800^{\mathrm{a}}$ & 2.387 & $10.900^{\mathrm{c}}$ & 1.399 & $13.600^{\mathrm{b}}$ & 2.305 \\
Silt\% & $34.600^{\mathrm{b}}$ & 2.560 & $37.900^{\mathrm{a}}$ & 2.737 & $29.700^{\mathrm{c}}$ & 2.606 \\
Sand\% & $47.600^{\mathrm{c}}$ & 3.439 & $51.200^{\mathrm{b}}$ & 3.675 & $56.700^{\mathrm{a}}$ & 3.400 \\
Density of & $0.000^{\mathrm{b}}$ & 0.000 & $0.667^{\mathrm{a}}$ & 0.017 & $0.000^{\mathrm{b}}$ & 0.000 \\
P. uloptera & & & & & & \\
Density of & $0.000^{\mathrm{b}}$ & 0.000 & $0.000^{\mathrm{b}}$ & 0.000 & $0.240^{\mathrm{a}}$ & 0.022 \\
P.pabularia & & & & & & \\
Total Canopy & $46.150^{\mathrm{c}}$ & 0.389 & $56.200^{\mathrm{a}}$ & 0.957 & $52.450^{\mathrm{b}}$ & 0.657 \\
Cover\% & & & & &
\end{tabular}

Same letters in a row indicate no significant difference. 
By using the discriminant analysis of habitats based on environmental factors and the results obtained, the two functions justified respectively $69.8 \%$ and $32 \%$ and a total of $100 \%$ of the variance of total data. Moreover, the canonical correlation coefficient showed that the Functions 1 and 2 were able to discriminate well between the groups (Table 3). Table 4 indicates the values of Wilks' lambda for functions, which increase from the Function 1 through the Function 2. The index closer to zero shows more appropriate estimated function in discrimination of groups, so Functions 1 and 2 had proper estimation in discrimination of groups. Considering the significance of chisquare values at the level of $<0.01$, the mean groups are different. In each of the Functions 1 and 2, the study parameters had different coefficients, so that the factors influencing the grouping of habitats as well as the distribution of the species studied can be determined, thanks to these coefficients (Table 5). Accordingly, the slope, clay, sand, silt, $\mathrm{pH}$, organic matter, temperature, aspect, potassium and precipitation are effective in discrimination of habitats and the distribution of the species studied. Clay and temperature, having the highest standardized coefficients, as well as potassium and organic matter, having the lowest standardized coefficients, respectively had the maximum and minimum impacts on the first detection function. The average annual precipitation has the greatest effect on Function 2. Owing to structural coefficients (Table 5), slope, clay, EC, potassium and sand in the first function, as well as $\mathrm{pH}$, silt, organic matter, elevation, temperature, nitrogen, aspect, potassium and precipitation in the second function, show the most correlation with functions formed. According to stepwise discriminant analysis, the functional equation can be set as Function 1 using canonical discriminant function coefficients, where factors involving $\mathrm{pH}$, organic matter, potassium, slope, aspect, clay, silt, sand, phosphorus, and average temperature have been included into the equation.

$$
\begin{aligned}
& Y_{1}=-1.437 \mathrm{pH}-0.365 \mathrm{OM}-0.002 \mathrm{~K}+0.041 \text { Slope }-0.010 \text { Aspect }- \\
& 0.320 \text { Clay }-0.068 \text { Silt }+0.121 \text { Sand }+0.016 P_{(\mathrm{mm})}+1.184 T_{(\mathrm{Cs})}-4.988
\end{aligned}
$$

The results of the classification of habitats studied by discriminant analysis are shown in Table 6. The percentages presented in this table show the matching level of observed and predicted cases. If the two species are in sites without Function 1 function properly, they determine membership of the Group 1 in 100 per cent of cases. If the data of absence of two species are in the first function, the function will properly determine membership of the Group 1 in 100 per cent of cases. If the data of P. uloptera are in the Function 1, the function will properly determine membership of the Group 2 in 99.20 per cent of cases. If the data of $P$. pabularia are in Function 1 , the function will properly determine membership of Group 3 in 98.30 per cent of cases. Overall, $99.40 \%$ of the main grouped cases have been properly classified. Accordingly, the results of this investigation indicated the effects of environmental factors on discrimination of habitats of studied species and the sites without the two species (Figure 2). In this figure, Group 1 represents the sites without the two species, Group 2 reflects the habitats of $P$. uloptera, and Group 3 shows the habitats of $P$. pabularia. 


$$
-964-
$$

Table 3. Eigenvalues and the percentage of variance explained by the two first functions

\begin{tabular}{c|c|c|c|c}
\hline Function & Eigenvalue & Variance (\%) & $\begin{array}{c}\text { Cumulative } \\
(\boldsymbol{\%})\end{array}$ & Canonical correlation \\
\hline 1 & $7.062^{\mathrm{a}}$ & 69.8 & 69.8 & $\mathbf{0 . 9 3 6}$ \\
2 & $3.048^{\mathrm{a}}$ & 30.2 & 100.0 & $\mathbf{0 . 8 6 8}$ \\
\hline
\end{tabular}

a. First 2 canonical discriminant functions were used in the analysis.

Table 4. Wilks' lambda values in discriminant analysis

\begin{tabular}{c|c|c|c|c}
\hline Test of function(s) & Wilks' lambda & Chi-square & df & Sig. \\
\hline 1 through 2 & 0.031 & 1225.138 & 24 & $\mathbf{0 . 0 0 0}$ \\
2 & 0.247 & 491.507 & 11 & $\mathbf{0 . 0 0 0}$ \\
\hline
\end{tabular}

Table 5. Standardized canonical discriminant function coefficients and structure matrix in the sites studied

\begin{tabular}{l|c|c|c|c}
\hline \multicolumn{2}{r|}{ Standardized canonical discriminant function } & \multicolumn{2}{c}{ Structure matrix } \\
\hline & \multicolumn{2}{|c|}{ Function } & \multicolumn{2}{c}{ Function } \\
\cline { 2 - 5 } & $\mathbf{1}$ & $\mathbf{2}$ & $\mathbf{1}$ & $\mathbf{2}$ \\
\hline Slope\% & 0.428 & -0510 & $\mathbf{0 . 3 1 5 ^ { * }}$ & -0.027 \\
EC (Ds/m) & - & - & $\mathbf{0 . 2 5 9}^{*}$ & 0.060 \\
Clay\% & $\mathbf{- 1 . 4 5 8}$ & 0.129 & $\mathbf{- 0 . 2 3 7 ^ { * }}$ & 0.154 \\
P(ppm) & - & - & $\mathbf{- 0 . 1 4 8}^{*}$ & -0.022 \\
Sand\% & 0.895 & 0.060 & $\mathbf{0 . 1 4 3}^{*}$ & 0.124 \\
pH & -0.221 & 0.182 & -0.111 & $\mathbf{0 . 1 8 4}^{*}$ \\
Silt\% & -0.595 & -0.205 & 0.001 & $\mathbf{0 . 1 8 1}^{*}$ \\
OM\% & -0.192 & -0.380 & 0.008 & $\mathbf{- 0 . 1 8 0}^{*}$ \\
Elevation (m) & - & - & 0.005 & $\mathbf{- 0 . 1 7 1}^{*}$ \\
Temperature (C) & $\mathbf{1 . 2 5 9}$ & 0.209 & 0.011 & $\mathbf{0 . 1 5 0}^{*}$ \\
N\% & - & - & 0.037 & $\mathbf{- 0 . 1 4 9}^{*}$ \\
Aspect & -0.789 & -0.109 & 0.057 & $\mathbf{- 0 . 1 0 3}^{*}$ \\
K (ppm) & -0.174 & 0.310 & -0.002 & $\mathbf{- 0 . 0 6 0}^{*}$ \\
Precipitation & 0.980 & $\mathbf{0 . 5 2 1}$ & 0.004 & $\mathbf{0 . 0 5 0}^{*}$ \\
(mm) & & & & \\
\hline
\end{tabular}

Table 6. The results of classification using discriminant analysis

\begin{tabular}{|c|c|c|c|c|c|}
\hline \multicolumn{6}{|c|}{ Classification results $^{\mathrm{a}}$} \\
\hline & \multirow[b]{2}{*}{ site } & \multicolumn{3}{|c|}{ Predicted group membership } & \multirow[b]{2}{*}{ Total } \\
\hline & & $\begin{array}{c}\text { Absence of two } \\
\text { species }\end{array}$ & $\begin{array}{c}\text { P. } \\
\text { uloptera }\end{array}$ & $\begin{array}{c}P . \\
\text { pabularia }\end{array}$ & \\
\hline \multirow{3}{*}{ Original $\%$} & $\begin{array}{c}\text { Absence of two } \\
\text { species }\end{array}$ & 100.0 & 0.0 & 0.0 & 100.0 \\
\hline & P. uloptera & 0.8 & 99.2 & 0.0 & 100.0 \\
\hline & P. pabularia & 0.0 & 1.7 & 98.3 & 100.0 \\
\hline
\end{tabular}

a.99.4\% of original grouped cases correctly classified. 


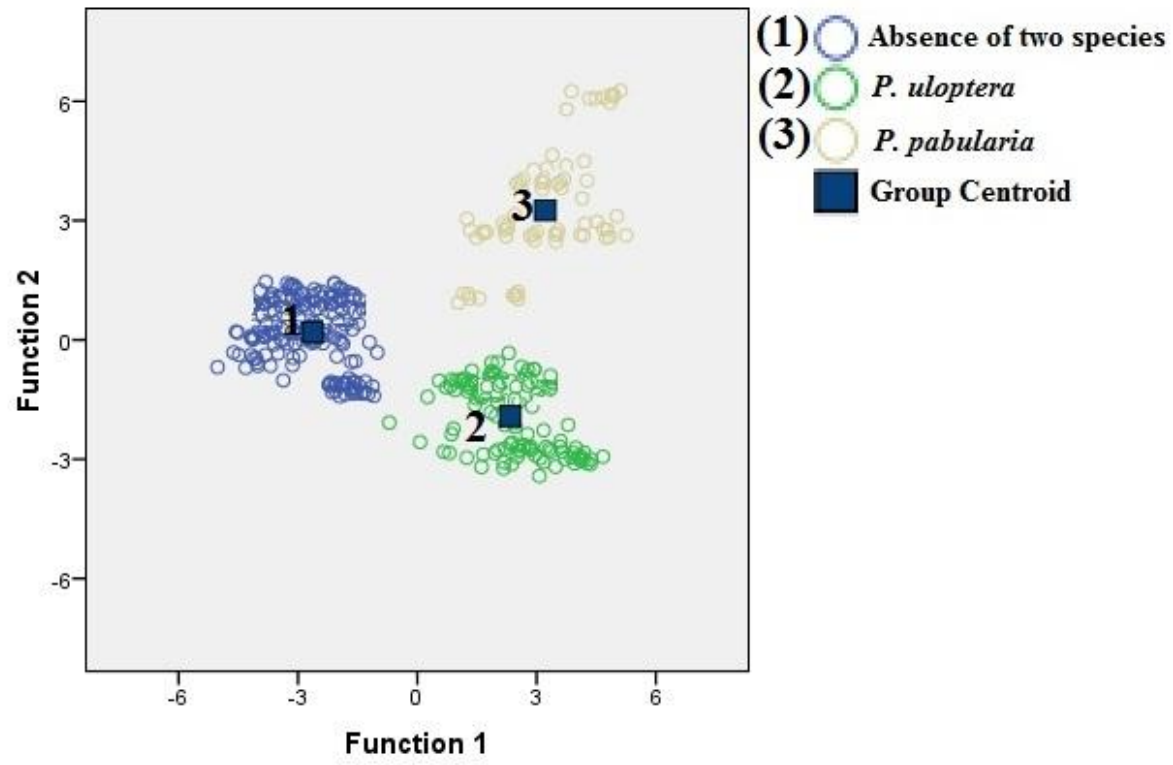

Figure 3. Canonical discriminant functions in the conditions of presence and absence of species

\section{Discussion and conclusion}

Establishment of plant communities occurs under the terms of climate and environmental conditions of the habitat; the plants are not randomly distributed across the globe. It is possible distribution of any plant in specific geographic limitation because any plant has specific environmental requirements that, if have in a certain area of growth and reproduction, these requirements must be provided. Comparison of the selected ecological factors in the habitats with the presence or absence of species demonstrated that most of the variables had significant differences. According to the field studies, no $P$. pabularia was found in sites with elevations $>1,700$ metres and $P$. uloptera had greater density in the higher elevations. Thus, the ecological requirements of these species appear to be different, and environmental characteristics of the distribution ranges of these species will have different effects. According to Ghorbani et al. (2015), the most important factors in the separation of plant species were reported to be elevation, slope percentage, soil texture, and depth in the southeastern rangelands of Sabalan. Moreover, Zhang and Dong (2010), in their study of the relationships between environmental factors and vegetation diversity, observed that elevation, soil type, slope and aspect were important factors in Lesi zones' recovery and played determinant roles in vegetation distribution. The precipitation and temperature were the study factors which, in turn, are affected by the elevation, and had significant differences among habitats in the study-so that $P$. pabularia in sites with higher precipitation and temperature and $P$. uloptera in sites with lower precipitation and temperature are more compatible. Ghorbani and Asghari (2014) also emphasized that precipitation and temperature can affect the distribution of Festuca ovina in southeastern rangelands of Sabalan, Ardabil, Iran. The organic matter content was the factor that had a significant impact on the distribution of the species studied. The organic matter content in the habitats of $P$. uloptera was more than in the habitats of $P$. pabularia. The density and total canopy cover were higher in the habitats of $P$. uloptera than the habitats of $P$. pabularia, probably due to the large amount of litter in these habitats. Soil organic matter within the rangeland system provides more nutrients for plant growth, which 
results in a positive feedback, as more plant biomass is likely to produce more soil organic matter (Ryals et al., 2014). Additionally, organic matter affects soil chemicals, physical and biological properties, and this has been suggested as the single most important indicator of soil quality (Xu et al., 2008b; Ryals et al., 2014; Mirzaei Mossivand and Bahrami, 2015).

The results of many studies showed that OM was one of the soil characteristics affecting the distribution of vegetation that was in agreement with the results of Salama et al. (2013), Zare et al. (2011), He et al. (2007) and Abd El-Ghani and Amer (2003). Kooch et al. (2007), in their study of ecological distribution of indicator species and effective soil factors in Mazandaran province, showed that the distribution of vegetation was correlated with soil properties such as soil texture, $\mathrm{P}, \mathrm{OM}, \mathrm{N}$ and $\mathrm{pH}$. According to the results, both $P$. uloptera and $P$. pabularia species prefer often soils with sandy-loam textures, and this means that they are more compatible with lighter textured soils. The soil texture affects the penetration and retention of water, and the availability of water and nutrients in plants (Sperry and Hacke, 2002). Soil texture controls dynamics of soil organic matter in many simulation models or organic matter decomposition and formation (Raich et al., 1991), and influences infiltration and moisture retention and the availability of water and nutrients by plants (Sperry and Hacke, 2002). Some studies, such as of Xu et al. (2008a) and Zarei et al. (2010), proved that the soil texture (clay, silt and sand) is one of the most important factors affecting plant type distribution. Results of Abbadi and El Sheikh (2002) and Davies et al. (2006) showed that soil texture is the most important factor in the separation of ecological groups. The results of discriminant analysis showed that slope, clay, sand, silt, $\mathrm{pH}$, organic matter, temperature, aspect, potassium and precipitation contribute to the discrimination of the habitats and the distribution of the species studied. Ghorbani et al. (2015) and Jafarian et al. (2010) also stated that the use of discriminant analysis in the relationship between environmental factors and distribution of vegetation has been beneficial. As the findings were presented, if the eigenvalues and canonical correlation coefficient are higher, the function obtained will be stronger, and the accuracy of classification will be greater. Discrimination variables that entered into the functions belonged to all the climatic, soil and topographic factors, representing the right choice of the parameters. In general, it can be stated that the functions resulting from discriminant analysis could be applied to the same species in other sites, using the findings of the present study, and identifying factors influencing the presence and absence of the species studied in the rangelands of Ardabil, thereby saving time required for similar studies. Details of this study can be useful in the optimal management of the rangelands. In addition, according to the survey results and discrimination of the habitats related to the species studied and the effects of ecological factors on their distribution, these findings could be used in the improvement and restoration of the same rangelands.

\section{REFERENCES}

[1] Abbadi, G.A., El Sheikh, M.A. (2002): Vegetation analysis of Failaka Island (Kuwait). Journal of Arid Environments 50: 153-163.

[2] Abd El-Ghani, M. M., Amer, W. M. (2003): Soil- vegetation relationships in a coastal desert plain of southern Sinai, Egypt. - Journal of Arid Environments 55: 607-628. 
[3] Akbarlou, M., Nodehi, N. (2016): Relationship between some environmental factors with distribution of medicinal plants in Ghorkhud protected region, Northern Khorasan Province, Iran. - Journal of Rangeland Science 6 (1): 63-72.

[4] Araújo, M. B., Guisan, A. (2006): Five (or so) challenges for species distribution modelling. - Journal of Biogeography 33: 1677-1688.

[5] Arundel, S. (2002): Modeling climate limits of plants found in Sonoran Desert packrat middens. - Quaternary Research 58: 112-121.

[6] Arundel, S. (2005): Using spatial models to establish climatic limiters of plant species' distributions. - Ecological Modelling 182: 159-181.

[7] Ashcroft, M. B., French, K. O., Chisholm, L. A. (2011): An evaluation of environmental factors affecting species distributions. - Ecological Modelling 222: 524-531.

[8] Azimi, F., Talaei, R., Asiabizade, F., Houshyar, M. (2011): Introduce the flora, life forms and geographical distribution of plant species forest and protected area Fandogloo (Ardabil Province). - Taxonomy and Biosystematics 3 (9): 75-88. (In Farsi).

[9] Chuangye, S., Hongxu, R. Chong, H. (2015): Test the relative importance of biotic and abiotic factors on species distribution - A case study in the Yellow River Delta. - Acta Ecologica Sinica 35: 59-64.

[10] Davies, K.W., Bates, J.D., Miller, R.F. (2006): Vegetation characteristics across part of the Wyoming big sagebrush alliance. - Rangeland Ecology \& Management 59: 567-575.

[11] Ghorbani, A., Asghari A. (2014): Ecological factors affecting the distribution of Festuca ovina in Southeastern rangelands of Sabalan. - Journal of Range and Desert Research 21 (2): 368-381. (In Farsi).

[12] Ghorbani, A., Abbasi, M., Asghari, A., Omidi, A. Zare Hesari, B. (2015): Compare ecological factors affecting distribution species Artemisia fragrans Willd. And Artemisia austriaca Jacq. in southeastern rangelands of Sabalan. - Journal of Rangeland 9 (2): 129141. (In Farsi).

[13] He, M. Z., Zheng, J. G., Li, X. R. Qian, Y. L. (2007): Environmental factors affecting vegetation composition in the Alxa Plateau, China. - Journal of Arid Environments 69: 473-489.

[14] Jafarian, Z., H., Arzani, M., Jafari, G., Zahedi, H., Azarnivand, H. (2010): Application of discriminate analysis for determination relationship between distribution of plant species with environmental factors and satellite data at Rineh rangeland in province of Mazandaran. - Journal of Pajouhesh \& Sazandegi 88: 64-71.

[15] Kent, M., Coker, P. (1996): Vegetation description and analysis: a practical approach. New York, John Wiley, 363.

[16] Kerbs, C. J. (1999): Ecological methodology. (2nd ed). - Addison Wesly Longman, Menlo Park, California, USA.

[17] Kooch, Y., Bahmanyar, H. J. M. A., Pormajidian, M. R. (2007): Ecological distribution of indicator species and effective edaphical factors on the Northern Iran lowland forests. - Journal of Applied Science 7: 1475-1483.

[18] Mirzaei Mossivand, A., Bahrami, B. (2015): The most important environmental factors effective on Dorema aucheri Boiss. Dispersion in Rangelands Lorestan provice. - Journal of natural ecosystem Iran 6 (2): 194-207.

[19] Mozaffarian, V. (2007): Umbelliferae. - In: Flora of Iran, No. 54. (Assadi, M., Khatamsaz, M., Maasoumi, A. A. eds.). Research Institute of Forests and Rangelands, Tehran, 596. (In Farsi).

[20] Murray, K., Conner, M. M. (2009): Methods to quantify variable importance: implications for the analysis of noisy ecological data. - Ecology 90: 348-355.

[21] Northup, B. K., Brown, J. R., Holt, J. A. (1996): Grazing impact on the spatial distribution of soil microbial biomass around tussock grasses in tropical grassland. Journal of Applied Soil Ecology 13: 259-270. 
[22] Platts, P. J., McClean, C. J., Lovett, J. C., Marchant, R. (2008): Predicting tree distributions in an East African biodiversity hotspot: model selection, data bias and envelope uncertainty. - Ecological Modelling 218: 121-134.

[23] Raich, J. W., Rastetter, E. B., Melillo, K. M., Kicklighter, D. W., Steudler, P. A., Peterson, B. J., Grace, A. L., Moore, B., Vorosmarty, C. J. (1991): Potential net primary productivity in South America: application of a global model. - Ecological Applications 1: 399-429.

[24] Rechinger, K. H. (1987): Apium (Apiaceae) - In: Rechinger, K. H. (ed.) Flora Iranica no. 162: 298-300. - Graz: Akademische Druck und Verlagsanstalt.

[25] Ryals, R., Kaiser, M., Torn, M. S., Berhe, A. A, Silver, W. L. (2014): Impacts of organic matter amendments on carbon and nitrogen dynamics in grassland soils. - Soil Biology \& Biochemistry 68: 52-61.

[26] Sahragard, H. P., Zare Chahouki, M. A. (2015): An evaluation of predictive habitat models performance of plant species in Hoze soltan rangelands of Qom province. Ecological Modelling 309-310: 64-71.

[27] Salama, F., Abd El-Ghani, M.M., El-Tayeh, N. (2013): Vegetation and soil relationships in the inland wadi ecosystem of central Eastern Desert, Egypt. - Turkish Journal of Botany 37 (3): 489-498.

[28] Sperry, J. S., Hacke, U. G. (2002): Desert shrub water relations with respect to soil characteristics and plant functional type. - Journal Functional Ecology 16: 367-378.

[29] Teimoorzadeh, A., Ghorbani, A. Kavianpoor, H. (2015): Study on the flora, life forms and chorology of the south eastern of Namin forests (Asi-Gheran, Fandoghloo, Hasani and Bobini), Ardabil province. - Journal of Plant Research (Iranian Journal of Biology) 28 (2): 264-275. (In Farsi).

[30] Xu, X-L., Ma, K-M., Fu, B-J., Song, C-J., Liu, W. (2008a): Relationships between vegetation and topography in a dry warm river valley SW Chin. - Catena 75: 138-145.

[31] Xu, Z., Chen, C., Burton, J., Ma, Q., Ge, Y., Xu, J. (2008b): Using light fraction and macroaggregate associated organic matters as early indicators for management-induced changes in soil chemical and biological properties in adjacent native and plantation forests of subtropical Australia. - Geoderma 147: 116-125.

[32] Yibing, Q. (2008): Impact of habitat heterogeneity on plant community pattern in Gurbantunggut Desert. - Journal of Geographical Sciences 14 (4): 447-455.

[33] Zare, S., Jafari, M., Tavili, A., Abbasi, H. R., Rostampour, M. (2011): Relationship between environmental factors and plant distribution in arid and semiarid area (Case Study: Shahriyar Rangelands, Iran). - American-Eurasian Journal of Agricultural \& Environmental Sciences 10(1): 97-105.

[34] Zarei, A., Zare-Chahouki, M., Jafari, M., Bagheri, H., Alizadeh, A. (2010): Determined of properties of soil effect on distribution of vegetation in mountain ranges of salt Qom province. - Journal of Rangeland 3: 412-421. (In Farsi).

[35] Zhang, J. T., Dong, Y. (2010): Factors affecting species diversity of plant communities and the restoration process in the loess area of China. - Ecological Engineering 36: 345- 350. 